\title{
Contents, Vol. 52, 1990
}

\section{No. 1 Original Paper}

Endolymphatic Sac Morphology following Long-Term Kanamycin Intoxication

Hultcrantz, M.; Bagger-Sjöbäck, D 1

Clinical Significance of Positive Summating Potential in Menière's Disease

Mori, N.; Koshimune, A.; Asai, H 10

Pre- and Postoperative High-Frequency Audiometry in Otosclerosis. A Study of 53 Cases

Tange, R.A.; Dreschler, W.A 16

Interaction of Excitatory and Inhibitory Stimuli on the Action Potential of the Semicircular

Canal in the Frog

Suzuki, M.; Harada, Y.; Hirakawa, H.; Omura, R 21

Disorders of Gaze during Head Rotation

Takahashi, M.; Saito, A.; Okada, Y.; Akiyama, I.; Tsujita, N

Prediction of Sequelae following Facial Nerve Palsy

Murata, K.; Nishimoto, C; Ohta, F 35

Interactions between Epstein-Barr Virus (EBV) and Human Cell Lines: Growth and EBV

Induction

Takimoto, T.; Iwawaki, J.; Tanaka, S.; Umeda, R 40

Malignant Fibrous Histiocytoma of the Hypopharynx

Kinishi, M.; Amatsu, M.; Makino, K.; Yamauchi, R.; Okada, S 47

Esophageal Foreign Bodies in Adults

Roura, J.; Morelló, A.; Comas, J.; Ferrán, F.; Colomé, M.; Traserra, J

Clinical Symptoms of Sleep Apnea Syndrome and Automobile Accidents

Haraldsson, P.-O.; Carenfelt, C; Diderichsen, F.; Nygren, Å.; Tingvall, C 57

Pathological Spot

Poorly-Differentiated Laryngeal Malignancies

Ferlito, A.; Friedmann, 163

Case Report

Quinine-Induced Hearing Loss

Nielsen-Abbring, F.W.; Perenboom, R.M.; van der Hulst, R.J.A.M 65

No. 2 Original Paper

Epstein-Barr Virus (EBV) Receptors on Epithelial Hybrid Cells Derived from Nasopharyngeal Carcinoma

Takimoto, T.; Tanaka, S.; Ishikawa, S.; Umeda, R 69

Blink Reflex: Prognostic Value in Acute Peripheral Facial Palsy

Ghonim, M.R.; Gavilan, C 75

Sealing of the Round Window Reversibly Affects Auditory Brainstem Response Latencies Spandow, O.; Anniko, M.; Möller, A.R 80

Steroid-Responsive Sensorineural Hearing Loss Associated with Aortitis Syndrome

Kunihiro, T.; Kanzaki, J.; O-Uchi, T.; Yoshida, A 86 
Expert Systems as a Diagnostic Aid in Otoneurology

Mira, E.; Buizza, A.; Magenes, G.; Manfrin, M.; Schmid, R 96

Vascular Events in Experimental Otitis Media Models: A Comparative Study

Goldie, P.; Hellström, S.; Johansson, U 104

The Epithelium of the Human Endolymphatic Sac: Immunohistochemical Characterization (With 1 color plate)

Altermatt, H.J.; Gebbers, J.-O.; Arnold, W.; Laissue, J.A 113

IV

Contents

Influence of Membrane Surface Potential and of Net Charge on Aminoglycoside Binding to the Organ of Corti of Guinea Pigs

Tran Ba Huy, P.; Deffrennes, D 121

Immunohistochemical Localization of Nonerythroid Spectrin (Fodrin) in the Sensory Cells

of the Vestibular End Organs of the Rat and Guinea Pig

Pirvola, U.; Ylikoski, J.; Virtanen, 1127

Case Report

Hemangiopericytoma as the Cause of Collet-Sicard Syndrome

Sehitoglu, M.A.; Üneri, C; Çelikoyar, M.M.; Tutkun, A.; Küllü, S 133

Announcements 74, 85

No. 3 Original Paper

Glycocalyx and Ciliary Interconnections of the Human Vestibular End Organs: An Investigation by Scanning Electron Microscopy

Takumida, M.; Suzuki, M.; Harada, Y.; Bagger-Sjöbäck, D 137

Human Endolymphatic Sac: Evidence for a Role in Inner Ear Immune Defence (With 1 color plate)

Altermatt, H.J.; Gebbers, J.-O.; Müller, C; Arnold, W.; Laissue, J.A

Clinical Factors Relating to the Positive Glycerol Test for Ménière's Disease

Yazawa, Y.; Kitahara, M.; Matsubara, H 149

Clinical and Audiological Characteristics of Tonal and Noise Tinnitus

Kodama, A.; Kitahara, M 156

Bell's Palsy: An Immune Complex Disease

Larsson, A.; Jonsson, L.; Sjöquist, J 164

Topical Anaesthesia of the Normal Tympanic Membrane: A Controlled Clinical Trial of

Different Suspensions of Lidocaine

Møller, Å.; Grøntved, A 168

Disaturated Phosphatidylcholine in Rabbit Eustachian Tube Surfactant

Mira, E.; Benazzo, M.; Tacconi, M.T.; Lligona, L.; Fumagalli, G.F.; Salmona, M. . 174 Wound

Healing of the Nasal Septal Perichondrium in Young Rabbits

Verwoerd, C.D.A.; Verwoerd-Verhoef, H.L.; Meeuwis, C.A.; v.d. Heul, R.0

180

Long-Term Survival of Patients with Paranasal Sinus Carcinoma

Anniko, M.; Franzén, L.; Löfroth, P.0 187

Pathology Spot

Laryngeal Fibrosarcoma: An Over-Diagnosed Tumor

Ferlito, A 194

Case Reports

Non-Infective Orbital Complications Resulting from Natural Defects of the Antral Roof. 


\section{Case Report}

Whittet, H.B.; McGlashan, J.; Croft, C.B 196

Plunging Ranula Localized in the Parapharyngeal Space

Takimoto, T.; Katoh, H.; Umeda, R 202

Announcements

179,201

Fig. 1. Normal human ES, proximal extraosseous part (exceptions: e = intermediate part); direct immu-nohistochemistry (frozen sections: a-f). a Monoclonal antibody LCA (CD45). Cells in the lumen, in the stroma and in the epithelium express CD45. The APAAP techniques yields red products. $\times 250$. b Monoclonal antibody DAKO T4 (CD4). CD4-posi-tive cells in intraepithelial (arrow), stromal (black and white arrowhead) and luminal locations (black arrowhead). APAAP. $\times$ 320. c Monoclonal antibody DAKO T8 (CD8). APAAP. $\times 320$. d Monoclonal antibody DAKO HLA-DR (HLA-DR). Mainly stromal cells express HLA-DR. APAAP. × 320. e Intermediate part; monoclonal antibody DAKO Pan B (CD22). Cells in the lumen (arrowhead and stroma (arrow) express CD22. APAAP. $\times$ 320. f Monoclonal antibody DAKO T6 (CD1). Only a few cells in the epithelium (arrow) express CD1. APAAP. $\times 320$. g Section of sublimateformaldehyde-fixed tissue; polyclonal antibody against lysozyme (muraminidase). Cells in the lumen (arrowhead) and stroma (arrow) display a positive reaction. PAP technique: brown histochemical products. $\times 370$. h Direct immunoflu-orescence; a polyclonal antibody against secretory component reacts strongly with epithelial cells and luminal contents. $\times 250$.

Contents

$\mathrm{V}$

No. 4 Original Paper

Effect of Sympathectomy on Capillaries of the Cochlear Lateral Wall

Watanabe, K.; Sugimoto, T.; Tsunoda, A 205

Effect of Anoxia on Spontaneous Discharges of the Cochlear Single Unit in Guinea Pigs

Kitano, H.; Kitahara, M; Suzuki, M 211

Caloric Nystagmus in Three Dimensions under Otolithic Control in Rhesus Monkeys.

A Preliminary Report

Arai, Y.; Suzuki, J.-L; Hess, B.J.M.; Henn, V 218

Difference between Visual Feedback and Visual Suppression upon the Stabilization of

Body Sway in Normal Subjects

Ohashi, N.; Asai, M.; Nakagawa, H.; Mizukoshi, K 226

Postural Stability in Shooters

Aalto, H.; Pyykkö, I.; Ilmarinen, R.; Kähkönen, E.; Starck, J

Retinoid-Induced Nasal Malformations

Granström, G.; Kullaa-Mikkonen, A 239

Studies on the Caldwell-Luc Operation with or without Counteropening at the Inferior Meatus

Saito, H.; Takanami, N.; Saito, T.; Wakui, S.; Fujieda, S 249

Epstein-Barr Virus Involvement in Salivary Gland Lesions Associated with Sjögren's Syndrome

Syrjänen, S.; Kärjä, V.; Chang, F.; Johansson, B.; Syrjänen, K 254 Influence of Perioperative Transfusion Therapy on the Recurrence Potential of Locally Advanced Laryngeal Carcinoma

Bongioannini, G.; Vercellino, M.; Rugiu, M.G.; Ferreri, A.; Succo, G.; Cortesina, G. . 260 


\section{Case Reports}

Branchial Cleft Fistula with Heterotopic Salivary Gland Tissue in the Lower Neck

Takimoto, T.; Kato, H265

Cavernous Hemangioma of the Frontal Bone

Sinnreich, Z.; Kremer, S.; Sade, J.; Bernheim, J 269

Announcements 253,264

No. 5 Original Paper

Reissner's Membrane in Aging, Menière’s Disease, and Profound Sensorineural Deafness

Quijano, M.L.; Kimura, R.S.; Fowler, K.B 273

Relationship between Results of Electrocochleography and Caloric Test in Menière's

Disease

Mori, N.; Asai, H.; Sakagami, M 281

Effect of Mechanical Trauma on the Stapedial Footplate after Stapedotomy. A Scanning

Electron Microscopic Study

Barbara, M.; Caggiati, A.; Attanasio, G.; Filipo, R 286

Tympanic Neurectomy: Its Effects on the Seromucinous Glands of the Middle Ear of

Cats

Elwany, S 292

Cisplatin Reduces Epidermal Growth Factor Receptors in Squamous-Cell Carcinoma in vitro. Preliminary Results

Bergler, W.; Bier, H 297

Contents

Laryngoplasty with Vascularized and Non-Vascularized Auricular Mucochondral Grafts.

An Experimental Study in Rabbits

Delaere, P.R.; Boeck, W.D.; Guelinckx, P.J.; Van de Voorde, W.V 303

Nasal Mucociliary Clearance in Patients with Nasal Polyposis

Coromina, J.; Sauret, J 311

Pathology Spot

Laryngeal Carcinoma Showing Multidirectional Epithelial Neuroendocrine and Sarcomatous Differentiation

Doglioni, C; Ferlito, A.; Chiamenti, C; Viale, G.; Rosai, J 316

Case Reports

Wegener's Granulomatosis with Otological Disorders as Primary Symptoms

Guyot, J.-P.; Baud, C; Montandon, P 327

Fluctuating Hearing Loss in Lipoma of the Cerebellopontine Angle

Kitamura, K.; Futaki, T.; Miyoshi, S 335

Announcements $\quad 340$

Original Paper

Effect of Dosing Schedule on Aminoglycoside Ototoxicity: Comparative Cochlear Ototoxicity of Amikacin and Isepamicin

Takumida, M.; Nishida, I.; Nikaido, M.; Hirakawa, K.; Harada, Y.; Bagger-Sjöbäck, D. 341

Functional Changes in the Brainstem Auditory Pathways following Open-Heart Surgery

Frenkel, A.; Zikk, D.; Rapoport, Y.; Vidne, B.; Himmelfarb, M.Z 350

Blood Pressure Abnormalities as Background Roles for Vertigo, Dizziness and Disequilibrium

Ohashi, N.; Imamura, J.; Nakagawa, H.; Mizukoshi, K 355

Optimizing of Electroneuronography of the Facial Nerve 
Neuwirth-Riedl, K.; Burian, M.; Nekahm, D.; Gstöttner, W 360

Ciliogenesis in Cultured Human Nasal Epithelium

Jorissen, M.; Van der Schueren, B.; Van den Berghe, H.; Cassiman, J.-J 368

Nasal Polyposis as a Risk Factor for Hypertension

Granström, G.; Jacobsson, E.; Jeppsson, P.-H 375

Case Reports

Osseous Hemangioma Arising in the Facial Bone

Nishimura, T.; Takimoto, T.; Umeda, R.; Kadoya, M.; Takashima, T.; Mizukami, Y. 385

Coincidental Radiographic Findings in Severe External Otitis in Nonimmunocompro-

mised Patients

Laurikainen, E.; Puhakka, H.; Rikalainen, H 391

Book Reviews

395

Author Index 396

Subject Index 397 